\title{
Skrining Senyawa Antiinfeksi dari Spons yang Dikoleksi dari Bunaken, Manado
}

\section{Screening of Anti-infectious Compounds of Sponges Collected from Bunaken, Manado \\ Puji Astuti' ${ }^{1)}$, Gemini Alam²), Sylvia Utami Tunjung Pratiwi' ${ }^{1)}$, Triana Hertiani' ${ }^{1)}$, Subagus Wahyuono ${ }^{1)}$}

${ }^{1)}$ Bagian Biologi Farmasi, Fakultas Farmasi, Universitas Gadjah Mada, Yogyakarta

${ }^{2)}$ Jurusan Farmasi, Fakultas MIPA, Universitas Hassanudin, Makasar

\begin{abstract}
The emergence of drug resistant and multidrug-resistant microbes as well as the lack of any current chemotherapy augmented the necessity to search for new and better antiinfective drug.. This study was aim to screen potential antiinfective extracts of sponges collected from Bunaken, Manado and to report on their antibacterial and antifungal properties. Testing for antiinfective agents was conducted using dilution method. Nutrient Agar was used as the testing media and nutrient broth for the inoculation of microorganisms. Staphylococcus aureus, Escherichia coli and Salmonella typhi were used as the testing bacteria and Candida albicans as the testing fungi. Chloramphenicol was used as positive control for anti bacterial activity and Ketokonazol for antifungi. The two acetone extracts tested (MD-O1 aceton and MD-02 aceton), all of them showed inhibition activities. Following partition with chloroform and methanol, all chloroform extracts inhibited the growth of both bacteria and fungi. These extracts then are considered to be potential candidates for further isolation and characterization as antiinfective agents.
\end{abstract}

Key words: screening, sponge, antibacterial, antifungi, Bunaken

Diterima: 16 September 2002, disetujui 12 Febuari 2003

\section{Pendahuluan}

Resistensi mikroba terhadap antibiotik klasik terjadi secara berkelanjutan dan terusmenerus. Tingginya kasus infeksi baik yang endemik ataupun epidemik serta penggunaan obat yang terus menerus merupakan faktorfaktor yang diduga sebagai penyebab terjadinya resistensi obat.

Suatu penelitian yang dilakukan di rumah sakit Chicago pada tahun 1952 menemukan beberapa strain Staphylococcus aureus yang resisten terhadap antibiotik eritromisin. Strain ini resistant terhadap pemberian obat konsentrasi $100 \mu \mathrm{g} / \mathrm{mL}$ dimana strain yang sensitif terbunuh pada konsentrasi 1 $\mu \mathrm{g} / \mathrm{mL}$ (Pratt, 1990). Penelitian serupa juga dikerjakan oleh Kbarek (2000) di rumah sakit Dr Sardjito Yogyakarta yang menemukan bahwa beberapa strain Bacillus sp, E. coli, K. pneumoniae dan Pseudomonas sp menjadi resisten terhadap beberapa antibiotik.

Kasus infeksi yang lain juga dilaporkan dari hasil survei tahun 1998 menyebutkan lebih dari satu juta manusia meninggal setiap tahun dikarenakan malaria (Rogers and Randolph, 2000). Munculnya strain mikroba dan malaria yang resisten terhadap berbagai macam obat serta meningkatnya jumlah kematian karena penyakit infeksi ini menunjukkan pentingnya penelitian untuk mencari senyawa antiinfeksi yang baru dan lebih baik (Wout, 1996; White, 1998).

Di lingkungan laut, selain tumbuhtumbuhan laut, hewan tak bertulang belakang seperti spons merupakan salah satu sumber senyawa-senyawa baru yang mempunyai keanekaragaman hayati tinggi dan penelitian 
yang telah ada terhadap spons telah menghasilkan senyawa-senyawa baru dengan struktur unik dan memiliki aktivitas farmakologis. Bioaktivitas senyawa yang diisolasi dari spons telah banyak dilaporkan, baik kemampuannya sebagai senyawa antibakteri, antifungi, antikanker dan insektisida (Ang et al., 2001; El Sayed, et al., 2001, Cafieri et al, 1995; Tsukamoto et al., 1999).

Skrining dan uji aktivitas senyawa yang terkandung dalam spons yang dikoleksi dari Bunaken, Manado perlu dilakukan sebagai langkah awal eksplorasi kekayaan alam laut Indonesia. Produk yang dihasilkan dari penelitian ini dapat dijadikan langkah awal upaya penemuan senyawa antiinfeksi baru yang diharapkan berpotensi tinggi untuk dikembangkan sebagai sumber obat baru.

\section{Metode Penelitian}

\section{Bahan}

Bahan utama spons diperoleh dari Taman laut Bunaken, Manado. Pengambilan spons menggunakan peralatan scuba diving. Ekstrak yang diperoleh diberi kode MD-01 $1_{\text {aseton }}$ dan MD-02 2 aseton, MD-01 ${ }_{\mathrm{CHCl}_{3 s o l},}$ MD-01 $1_{\mathrm{MeOHsol}}$ MD-02 ${ }_{\text {CHCl3sol, }}$ MD-02 $2_{\text {MeOHsol }}$; Nutrient Agar (Difco) digunakan sebagai media uji dan nutrient broth untuk pertumbuhan mikroba. Staphylococcus aureus, Escherichia coli dan Salmonella typhi digunakan sebagai bakteri uji dan Candida albicans untuk uji antijamur. Kloramfenikol digunakan sebagai kontrol positif bakteri dan ketokonazol sebagai kontrol positif jamur.

\section{Ekstraksi}

Ekstrak diperoleh dengan cara maserasi menggunakan aseton pa (E.Merck) sebagai pelarut. Pelarut diuapkan dengan bantuan rotavapor (Heidolph WB 2000). Ekstrak aseton yang diperoleh dipartisi dengan klorofom diikuti dengan metanol. Skema ekstraksi dapat dilihat pada Gambar 1.

\section{Uji Antibakteri dan Antijamur}

Uji antiinfeksi dilakukan menurut cara kerja yang tercantum pada Mitscher et al
(1972). Bakteri dan jamur uji dari biakan agar miring ditumbuhkan pada nutrient broth (NB) dan diinkubasi \pm 24 jam. Biakan dalam media cair tersebut diencerkan dengan air saline ( $\mathrm{NaCl} 0,9 \%)$ sampai kekeruhannya menyamai standar Mc. Farlan $\left(10^{8} \mathrm{CFU}\right)$. Ekstrak yang telah dilarutkan dalam DMSO $(200 \mu \mathrm{l})$ dicampurkan dengan nutrient agar (NA) yang telah dicairkan (volume akhir $10 \mathrm{ml}$ ). Campuran tersebut dituang ke dalam petridish dan dibiarkan memadat. Biakan yang telah diencerkan dalam air saline diambil sebanyak 5 $\mu \mathrm{l}$ dan diteteskan di atas media padat. Biakan tersebut diratakan menggunakan drigalsky (metode surface plate). Petridish diinkubasi pada suhu $37^{0} \mathrm{C}$ selama \pm 24 jam. Kloramfenikol digunakan sebagai kontrol positif (+) bakteri dan Ketokonazol sebagai kontrol positif (+) jamur dan kontrol negatif (-) dibuat dengan menumbuhkan bakteri atau jamur dalam media yang mengandung DMSO.

\section{Hasil dan Pembahasan}

Penelitian yang mengarahkan ke penemuan senyawa baru antimikroba terus meningkat. Dengan semakin tingginya kasus infeksi mikroba, kasus resistensi obat juga semakin meningkat. Usaha eksplorasi penemuan obat baru terus dilakukan mulai yang bersumber dari bahan alam darat sampai yang bersumber dari bahan alam laut. Potensi eksploitasi bahan alam laut sebagai sumber obat semakin menarik ditelusuri karena dapat menjanjikan ditemukannya senyawa-senyawa dengan struktur kimia yang baru dan unik. Biota laut spons diperoleh dari kedalaman 5-50 meter dan memiliki lingkungan tumbuh yang spesifik. Hal ini merupakan salah satu faktor pembeda antara sumber daya alam darat dan laut yang eksploitasinya relatif baru dimulai sejak 30 tahun yang lalu (Faulkner, 1993).

Pada penelitian ini skrining senyawa antimikroba dilakukan terhadap dua spesies spons yang dikoleksi dari Taman Laut Bunaken, Menado. Skrining aktivitas antibakteri diawali dengan maserasi bahan uji (MD-01 dan MD-02) dengan pelarut organik aseton. Pelarut ini dipilih dengan pertimbangan kemampuan mengekstraksi senyawa-senyawa polar dan non-polar dengan meminimalkan 
kontaminasi garam laut. Ekstrak aseton yang diperoleh selanjutnya dipartisi dengan kloroform untuk memisahkan senyawasenyawa non-polar dan bagian yang tidak larut diuapkan untuk kemudian dipartisi dengan metanol untuk mendapatkan senyawa-senyawa berpolaritas lebih tinggi (Gambar 1).

Uji aktivitas antibakteri dilakukan dengan metode dilusi padat dalam media nutrient agar dengan bantuan sejumlah kecil volume DMSO $(200 \mu \mathrm{l}$ dalam $10 \mathrm{ml}$ media) sebagai pelarut. Suatu ekstrak dikatakan aktif apabila dengan kadar pemberian $\leq 1000 \mu \mathrm{g} / \mathrm{ml}$ mampu menghambat pertumbuhan bakteri atau jamur yang ditandai dengan tidak adanya pertumbuhan mikroba pada media pertumbuhan (Hoffmann et al., 1993).

Pada percobaan ini seperti terlihat pada Tabel 1, diketahui bahwa ekstrak MD baik MD-01 $\left(\mathrm{CHCl}_{3}\right.$ dan $\left.\mathrm{MeOH}\right)$ maupun MD-02 $\left(\mathrm{CHCl}_{3}\right.$ dan $\left.\mathrm{MeOH}\right)$ dengan kadar $1000 \mu \mathrm{g} / \mathrm{ml}$ mampu menghambat pertumbuhan bakteri gram positif ( $S$. aureus) dan bakteri gram negatif (E. coli, Salmonella typhi). Akan tetapi ekstrak MD-02 $2_{\mathrm{MeOH}}$ mempunyai aktifitas menghambat pertumbuhan $E$. coli paling rendah dilihat dari masih tumbuhnya $E$. coli walaupun dalam jumlah yang sangat sedikit (Gambar 2g). Struktur dinding sel bakteri gram positif kemungkinan berpengaruh terhadap masuknya molekul besar ke dalam sel, karena diketahui bahwa dinding sel bakteri gram positif hanya terdiri dari lapisan peptidoglikan dan asam teikoat. Struktur dinding sel bakteri gram negatif lebih kompleks yakni pada bagian luar peptidoglikan terkandung tiga polimer yaitu lipoprotein, selaput luar dan liposakarida (Jawetz et al., 1995).

Hasil ekstraksi menunjukkan bahwa ekstrak aseton yang larut kloroform spons MD01 dan MD-02 mempunyai aktivitas penghambatan pertumbuhan jamur Candida albicans lebih tinggi dibanding ekstrak aseton yang larut dalam metanol. Kemampuan penghambatan ini dapat dilihat pada Gambar 2d dan 2e dibandingkan dengan Gambar $2 \mathrm{f}$ dan 2g. Pada media yang mengandung ekstrak kloroform MD-01 dan MD-02 tidak terdapat pertumbuhan mikroba uji dibandingkan dengan pada media yang mengandung ekstrak metanol MD-01 dan MD-02 yang masih terlihat adanya sedikit pertumbuhan, relatif terhadap kontrol. Hal ini berarti bahwa senyawa aktif antimikroba yang terdapat pada ekstrak-ekstrak spons tersebut bersifat non polar. Hasil penelitian ini juga didukung oleh aktivitas antibakteri senyawa manzamine yang bersifat relatif non polar yang diisolasi dari spons Xestospongia ashmorica (Endrada et al., 1996).

Hasil ekstrak kloroform spons MD-01 dan MD-02 sangat berpotensial dan dapat dijadikan kandidat dalam usaha penelusuran lebih lanjut senyawa yang bertanggung jawab terhadap penghambatan pertumbuhan mikroba. Kemampuan ekstrak kloroform spons MD-01 dan MD-02 sebagai antiinfeksi merupakan suatu sumbangsih bahan alam laut Indonesia dalam penemuan obat antiinfeksi. Seperti kita ketahui bahwa bakteri $S$. aureus, E. coli dan $S$. thypi merupakan bakteri yang banyak dilaporkan menjadi penyebab penyakitpenyakit infeksi pada manusia seperti diare, disentri dan tipus. Bakteri-bakteri ini banyak ditemukan pada makanan maupun air yang mengandung feces orang yang terinfeksi mikroba tersebut. Selain itu juga diketahui bahwa penyakit keputihan yang banyak menyerang kaum wanita ditimbulkan oleh jamur C. albicans.

\section{Kesimpulan}

Ekstrak kloroform MD-01 dan MD-02 mampu menghambat pertumbuhan bakteri dan jamur uji. Ekstrak-ekstrak ini dapat dijadikan kandidat yang sangat potensial untuk ditelusuri lebih lanjut kandungan senyawa aktifnya. Hasil penelitian ini dapat dijadikan dasar penelitian lebih lanjut mengenai upaya eksplorasi senyawa antiinfeksi baru yang berpotensi tinggi.

\section{Ucapan Terima Kasih}

Penelitian ini sebagian dibiayai oleh DIKS Fakultas Farmasi, Universitas Gadjah Mada 2002. 


\section{Daftar Pustaka}

Ang, K.K.H., Holmes, M.J.m Kara, U.A.K., 2001, Immune-mediated parasite clearance in mice infeted with Plasmodium berghei following treatment with manzamine A, Parasitol Res, 87:715-721.

Cafieri, F., Fattorusso, E., Mangoni, A., Taglialatela-Scafiati, O., 1995. Longamide and 3,7-dimethylisoguanine, Two Novel Alkaloids from the Marine Sponge Agelas longistima, Tetrahedron Letters. 36 (43):7893-7896.

El Sayed, K.A., Kelly, M., Kara, U.A.K., Ang, K.K.H., Katsuyama, I., Dunbar, D.C., Khan, A.A., Hamann, M.T., 2001. New Manzamine Alkaloids with Potent Activity against Infectious Diseases, J.Am. Chem.Soc. 123:1804-1808.

Faulkner, D.J., 1993, Academic Chemistry and Discovery of Bioactive Marine Natural Products, In: Attaway, D.H., and Zaborsky, O.R. (eds), Marine Biotechnology, Vol.1., Pharmaceutical and Bioactive Natural Products, Plenum Press, USA, 459-472.

Hoffmann, J.J., Timmermann, B.N., Meclaughlin, S.P., Punnapayak, H., 1993, Potential Antimicrobial Activity of Plants from Southwestern United States, Int. J. Pharmacog., 31(2), 101115.

Jawetz, E., Melnick, J.L., Adelberg, E., 1995. Medical Microbiology. Apleton \& Lange, New York, 18-22.
Kbarek, M., 2000, Uji resistensi mikroorganisme limbah RSUP dr. Sardjito terhadap antibiotik penghambat sisntesis protein. Skripsi. Fakultas Farmasi UGM.

Pratt WB, 1990, Drug resistance, In: Pratt WB, Taylor P (eds), Principles of drug action: The basis of pharmacology, Churchill Livingstone, USA, 565-637.

Rogers, D.J, Randolph, S.E., 2000. The Global Spread of Malaria in a Future, Marmer World. Science. 289, 1763-1766.

Tsukamoto, S., Yamashita, T., Matsunaga, S., dan Fusetani, N., 1999. Stellettazde A: An Antibacterial Guanidinoimidazole Alkaloid from a Marine Sponge Stelletta sp., Tetrahedron Letters. 40: 737-738.

White T.C., Marr, K.A., Bowden, R.A., 1998. Clinical, cellular and molecular factors that contribute to antifungal drug resistance, Clin. Microbiol. Rev. 1, 382402.

Wout, J van't., 1996. Fungal infection and antifungal drugs: has the age of antifungal resistance dawned?, Curr. Opin. Infect. Dis., 9, 63-66.

Tabel 1. Daya aktivitas antimikroba ekstrak aseton dan hasil partisinya dari spons yang dikoleksi dari Taman Laut Bunaken, Menado (konsentrasi pemberian $1000 \mu \mathrm{g} / \mathrm{ml}$ ). 


\begin{tabular}{|c|c|c|c|c|}
\hline \multirow[b]{2}{*}{ Nama sampel } & \multicolumn{3}{|c|}{ Jenis bakteri } & \multirow{2}{*}{$\begin{array}{c}\text { Jenis jamur } \\
\text { Candida albicans }\end{array}$} \\
\hline & S.aureus & E.coli & $\begin{array}{l}\text { S. ty } \\
\text { mphi }\end{array}$ & \\
\hline MD-01 $1_{\text {aseton }}$ & ++ & ++ & ++ & ++ \\
\hline MD-02 $2_{\text {aseton }}$ & ++ & ++ & ++ & ++ \\
\hline MD-01 $1_{\mathrm{CHCl} 3 \mathrm{sol}}$ & ++ & ++ & ++ & ++ \\
\hline MD-02 ${ }_{\text {CHCL3sol }}$ & ++ & ++ & ++ & ++ \\
\hline MD-01 $1_{\mathrm{MeOHsol}}$ & ++ & ++ & ++ & + \\
\hline MD-02 $\mathrm{MeOHsol}$ & ++ & + & ++ & + \\
\hline Kontrol (+) bakteri kloramphenikol & ++ & ++ & ++ & ++ \\
\hline Kontrol (+) jamur Ketokonazol & ++ & ++ & ++ & ++ \\
\hline Kontrol (-) DMSO & -- & -- & -- & -- \\
\hline
\end{tabular}

Keterangan:

$++\quad=$ menghambat pertumbuhan bakteri/jamur (active, complete inhibition, no growth)

$+\quad=$ sedikit pertumbuhan bakteri/jamur (low activity, partial growth, relative to the control)

-- $\quad=$ pertumbuhan bakteri/jamur tidak terhambat (inactive, complete growth, relative to the control)

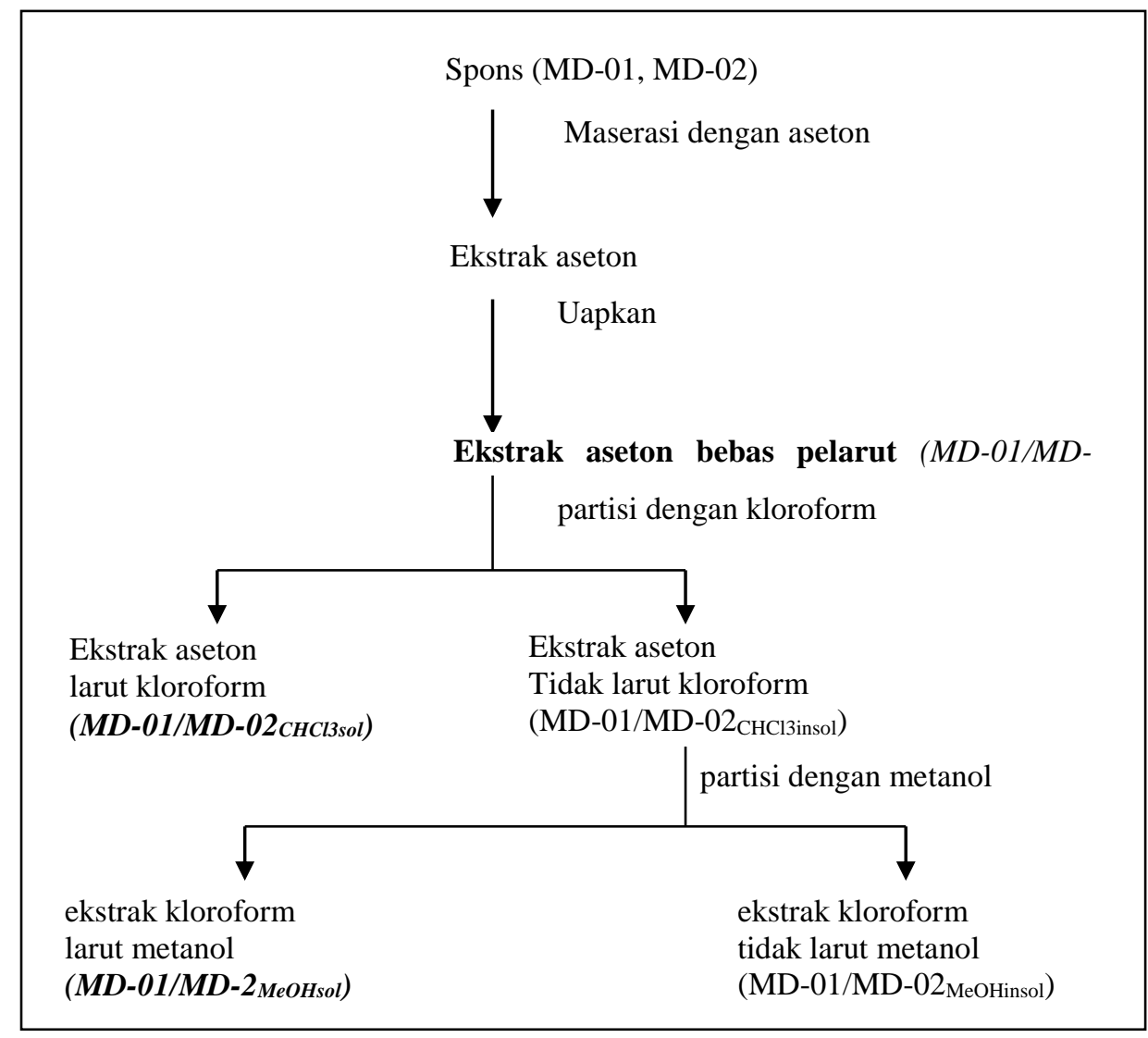

Gambar 1. Skema kerja cara ekstraksi spons (Ekstrak yang diuji ditandai dengan huruf tebal dan bergaris miring) 


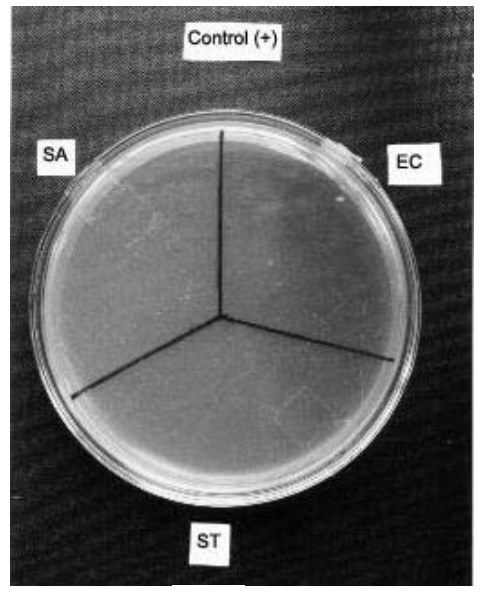

(a.)

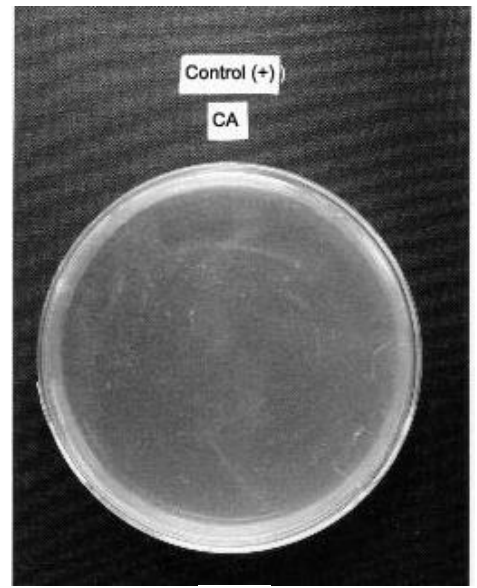

(b.)

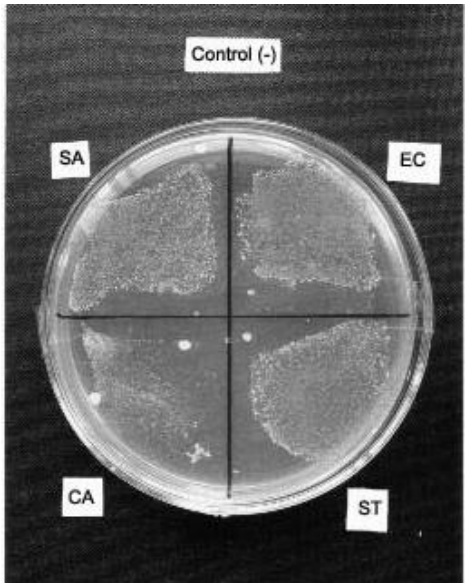

(c.)

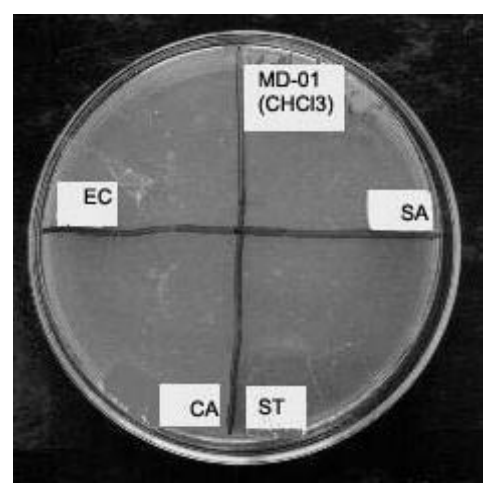

(d.)

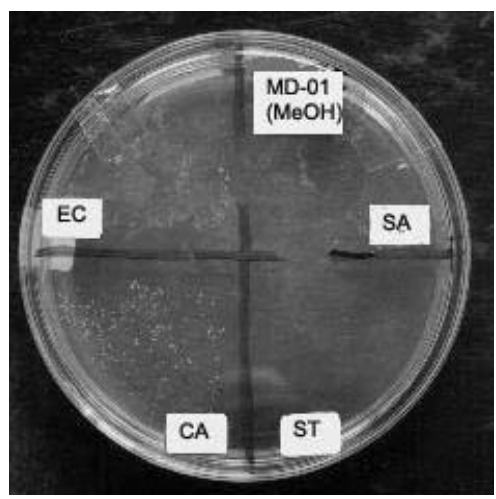

(f.)

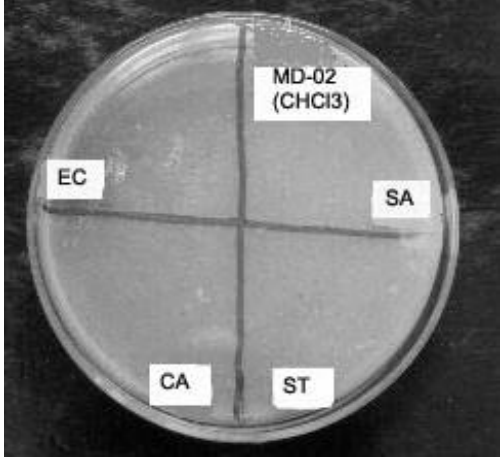

(e.)

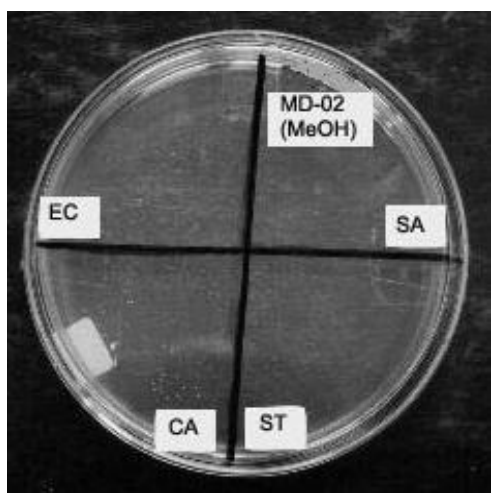

(g.)

Gambar 2. Daya Penghambatan Ekstrak MD-01/MD-02 ${ }_{\text {CHCL3sol }}$ dan MD-01/MD-02 $2_{\text {MeOHsol }}$ terhadap bakteri gram positif dan negatif serta jamur uji. (a) kontrol positif bakteria (searah jarum jam, E. coli, S. typhi, S.aureus), (b) kontrol positif jamur C. albicans, (c) kontrol negatif bakteria dan jamur (searah jarum jam, E. coli, S. typhi, C. albicans, S.aureus), (d) aktivitas penghambatam ekstrak MD-01 ${ }_{C H C l 3 s o l}$, (e) aktivitas penghambatan ekstrak MD$02_{C H C l 3 s o l},(f)$ aktivitas penghambatan ekstrak MD-O1 $1_{\text {MeOHsol, }}(g)$ aktivitas penghambatan ekstrak MD-02 $2_{\text {MeOHsol. }}$ (d,e,f,g searah jarum jam S.aureus, S.typhi, C.albicans, E.coli) 